\title{
Epigenetically silenced miR-34b/c as a novel faecal-based screening marker for colorectal cancer
}

\section{Kalimutho*, , 2,7, S Di Cecilia', G Del Vecchio Blanco ${ }^{3}$, F Roviello ${ }^{4,5}$, P Sileri', M Cretella ${ }^{4}$, A Formosa', G Corso ${ }^{4,5}$, D Marrelli, ${ }^{4,5}$, F Pallone ${ }^{1,3}$, G Federici ${ }^{1,2}$ and S Bernardini ${ }^{*, 1,2}$}

'Department of Internal Medicine, University of Rome 'Tor Vergata', Rome, Italy; ${ }^{2}$ Department of Laboratory Medicine, UOC Clinical Molecular Biology and Biochemistry, University Hospital Tor Vergata, Viale Oxford 8I, Rome 00133 , Italy; ${ }^{3}$ Department of Internal Medicine, Gastroenterology Unit, University Hospital Tor Vergata, Rome, Italy; ${ }^{4}$ Department of Human Pathology and Oncology, Section of Advanced Surgical Oncology, University of Siena, Siena, Italy; ${ }^{5}$ Istituto Toscano Tumori, Firenze, Italy; ${ }^{6}$ Department of Surgical Oncology, University Hospital Tor Vergata, Rome, Italy

BACKGROUND: MicroRNAs are tiny non-coding small endogenous RNAs that regulate gene expression by translational repression, mRNA cleavage and mRNA inhibition. The aim of this study was to investigate the hypermethylation of miR-34b/c and miR- I 48a in colorectal cancer, and correlate this data to clinicopathological features. We also aimed to evaluate the hypermethylation of miR-34b/c in faeces specimens as a novel non-invasive faecal-DNA-based screening marker.

METHODS: The 5-aza-2'-deoxycytidine treatment and methylation-specific PCR were carried out to detect the hypermethylation of $\mathrm{miR}-34 \mathrm{~b} / \mathrm{c}$ and $\mathrm{miR}-148 \mathrm{a}$.

RESULTS: The miR-34b/c hypermethylation was found in $97.5 \%$ (79 out of 82 ) of primary colorectal tumours, $P=0.0110$. In $75 \%$ (21 out of 28) of faecal specimens we found a hypermethylation of miR-34b/c while only in 16\% (2 out of I2) of high-grade dysplasia. In addition, miR-I48a was found to be hypermethylated in 65\% (5I out of 78) of colorectal tumour tissues with no significant correlation to clinicopathological features. However, a trend with female gender and advanced age was found, $P=0.083$. We also observed a trend to lower survival rate in patients with miR-148a hypermethylation with 10-year survival probability: 48 vs $65 \%$, $P=0.561$

CONCLUSIONS: These findings show that aberrant hypermethylation of miR-34b/c could be an ideal class of early screening marker, whereas miR-148a could serve as a disease progression follow-up marker.

British Journal of Cancer (201I) 1 04, 1770-1778. doi:I0.1038/bjc.201 I.82 www.bjcancer.com

(c) 20II Cancer Research UK

Keywords: miR-34b/c; miR-I48a; methylation; faeces; CRC

MicroRNAs (miRNAs) are a class of small regulatory non-coding RNAs of $\sim 22$ nucleotides in length that modulate specific cellular activity post transcriptionally. The miRNAs target the posttranslation level of mRNA through a sequence-specific complimentary at the $3^{\prime}$ UTR region of a gene, thus inhibiting gene expression (Lee et al, 1993; Wienholds et al, 2005). The human genome is encoded by at least $3 \%$ miRNAs, and up to $30 \%$ of human protein encoding genes may be regulated by miRNA modulation (Sassen et al, 2008). The miRNAs are shown to have key roles in normal development and also in differentiation, cell proliferation and apoptosis of cancer cells (Bartel, 2004; He et al, 2005). In the miRBase, thousands of miRNA have been bioinformatically predicted for both prokaryote and eukaryote, and awaiting experimental validation. Each of these miRNA could potentially regulate up to several hundred genes at mRNA posttranslation level (Krek et al, 2005).

*Correspondence: Dr M Kalimutho; E-mail: m.kalimutho@qub.ac.uk or Professor S Bernardini; E-mail: bernardini@med.uniroma2.it

${ }^{7}$ Current address: Drug Resistant Group, Centre for Cancer Research and Cell Biology, Queen's University, Belfast, Northern Ireland, UK

Received 19 November 2010; revised 7 February 2011; accepted 16 February 2011
Previous study has shown that more than $50 \%$ of the miRNA genes are located in cancer-associated genomic regions or in fragile sites which are hot spots for gene deletion, amplification and mutations (Calin et al, 2004), suggesting major functions for miRNAs in cancer cell biology. Furthermore, miRNAs also have been shown to be involved in a wide variety of human cancers, including colon, pancreatic, breast, prostate, liver and ovarian cancer, suggesting a more negative regulation of cancer cell growth by miRNAs modulation (Michael et al, 2003; Gramantieri et al, 2007; Hurteau et al, 2007; Lee et al, 2007; Shi et al, 2007; Barbarotto et al, 2008; Felicetti et al, 2008; Mitomo et al, 2008). Initially, miR-15 and miR-16 were shown to be involved in the pathogenesis of chronic lymphocytic leukaemia (Calin et al, 2002), and later He et al (2005) and Johnson et al (2005) described a relationship between a miRNA cluster of mir-17-92 with Myc oncogenic pathway.

One of the processes that tightly link miRNAs and cancer is the process called epigenetic modification. This epigenetic alteration in cancer has been shown to occur together with the genetic alterations in colorectal cancer (CRC). Thus, the aberrant hypermethylation process drives the initiation and the progression of colorectal polyps towards invasive of advanced stage colorectal tumours. Two recent studies have addressed the involvement of epigenetically silenced miRNA genes in CRC tumourigenesis including $\mathrm{miR}-34 \mathrm{~b} / \mathrm{c}$ and $\mathrm{miR}-342$. Moreover, miR-148a has also 
recently been discovered to be involved in metastasis progression in several cancers including in CRC. Therefore, the understanding of the early process of miRNAs methylation signature in CRC is of utmost important to define the actual tumourigenesis process involved, other than that of hypermethylation protein coding tumour suppressor genes (Grady et al, 2008; Toyota et al, 2008).

Analysing the promoter methylation of cancer-related genes has been always difficult, as it involved multiple steps for the conversion of unmethylated cytosine residues to uracil, but leaves 5-methylcytosine residues unaffected, particularly when analysing the samples derived from tumour specimens and bodily fluids. In this paper, we have applied the whole bisulfitome amplification method based on isothermal multiple displacement amplification technology. A uniquely processive DNA polymerase with a $3^{\prime}-5^{\prime}$ exonuclease proofreading activity maintains high fidelity during the replication process. This technique was developed using REPLI-g technology to allow reproducible and representative amplification of bisulfite converted DNA, while maintaining the converted sequence representation (for further details can access from http://www.qiagen.com/).

In this study, we investigate $\mathrm{miR}-34 \mathrm{~b} / \mathrm{c}$ and $\mathrm{miR}-148 \mathrm{a}$ hypermethylation pattern in CRC tissues and correlate it with clinicopathological features. Furthermore, we wanted to confirm whether miR-34b/c could be used as a possible screening marker for the detection of malignant colonocytes in faeces as a novel noninvasive method. We also aimed to determine the suitability of miR-148a as a prognosis factor for CRC. We showed that miR-34b/c could be an ideal candidate target for CRC screening in faecal microenvironment, whereas the involvement of epigenetic silencing factor in miR-148a correlates to poor prognosis.

\section{MATERIALS AND METHODS}

\section{CRC cell lines and drug treatment}

The CRC cell lines used in this study were HCT116, HT29, LoVo and HCT15. All cell lines were tested for mycoplasma infection and were grown in monolayer cultures in DMEM (HCT116, HT29), RPMI 1640 (HCT15) and Ham's Nutrients mix F12 (LoVo) supplemented with $10-20 \%$ FBS and $1 \%$ penicillin streptomycin according to UKCCCR guidelines (Masters et al, 2000) and as previously reported (Kalimutho et al, 2010a). No antibiotics were added to the medium before the treatment. The cells were trypsinised and passed twice a week and the experiments were conducted at early passages. Later the cells were treated with 5-aza- $2^{\prime}$-deoxycytidine (AZA; Sigma-Aldrich, St Louis, MO, USA) for 5 days.

\section{Quantitative PCR (qPCR)}

RNA isolation, cDNA synthesis and $R T-q P C R$ Total RNA was isolated using miRNeasy kit according to the manufacturer's guideline (Qiagen, GmbH, Hilden, Germany). The integrity of total RNA was determined by $1 \%$ agarose gel electrophoresis. Applied Biosystems RT-qPCR primer sets for miRNA-specific reverse transcription (Ambion Inc., TX, USA) including RNU19 and
RNU6B was used according to the manufacturer's protocol. Briefly, the reaction master mix containing $5 \times \mathrm{RT}$ Buffer, $5 \times \mathrm{RT}$ Primer, Array-Script Enzyme Mix (Applied Biosystems, Foster City, CA, USA) and nuclease-free water was mixed with $50 \mathrm{ng}$ of input miRNA. The mixture was incubated for $30 \mathrm{~min}$ at $37^{\circ} \mathrm{C}$ and then for $10 \mathrm{~min}$ at $95^{\circ} \mathrm{C}$. The $\mathrm{qPCR}$ was carried out using the Stratagene Real-Time PCR System (Stratagene, Agilent Technologies, Santa Clara, CA, USA) with Applied Biosystems qRT-PCR miRNA Detection Kit (Ambion Inc.). The PCR master mix containing Applied Biosystems $2 \times$ PCR Buffer (with FAM labelled Taqman probe), $1 \mu$ l FAM-labeled-specific primers and cDNA from process miRNA (Applied Biosystems). The RT products was processed as follows: $95^{\circ} \mathrm{C}$ for $10 \mathrm{~min}$, and then for $95^{\circ} \mathrm{C}$ for $15 \mathrm{~s}$ and $60^{\circ} \mathrm{C}$ for $30 \mathrm{~s}$ for up to 40 cycles $(n=2)$. Fold changed expression following AZA treatment was calculated via a $2^{\wedge}-\Delta \Delta C_{\mathrm{q}}$ method.

\section{Tissues and faecal DNA}

The CRC with matched normal tissue samples were obtained from Surgery Unit of Tor Vergata University Hospital and from University of Siena, which were approved by both internal review boards. A total of 81 primary CRC tissues together with 42 matched control fresh frozen tissues were used for DNA extraction. Faecal DNA was extracted from 28 CRC patients, 39 healthy individuals and 12 patients with high-grade dysplasia (HGD) of colorectum.

\section{Isolation of miRNA and DNA from CRC and normal tissue samples}

Approximately $10-15 \mathrm{mg}$ of fresh frozen tissues of CRC and normal surrounding tissues were used to extract DNA using DNAeasy kit following the manufacturer's guideline (Qiagen).

\section{Bisulfite conversion of genomic DNA and methylation-specific PCR (MSP)}

Bisulfite conversion of genomic DNA was performed as described in Epitech Bisulphite Conversion kit (Qiagen) to create a template for MSP. Briefly, $1.5 \mu \mathrm{g}$ of genomic DNA from each sample in a volume of $20 \mu \mathrm{l}$ was mixed with an appropriate chemical solvent provided then processed accordingly. Finally, the converted DNA was re-suspended in $40 \mu$ l distiled water to a final concentration of 25-30 ng $\mu \mathrm{l}^{-1}$. Bisulfite-treated DNA was then used as template for MSP, which was performed following the methylation-specific primer (Table 1). Briefly, $2 \mu \mathrm{l}$ of bisulfite-converted genomic DNA served as the PCR template. The $1 \times$ PCR buffer supplemented with $1.5 \mathrm{mM} \mathrm{MgCl}_{2}, 0.25 \mathrm{~mm}$ of each primer, $0.2 \mu \mathrm{M}$ of dNTPs, $0.1 \mu \mathrm{g} \mu \mathrm{l}^{-1} \mathrm{BSA}$ and $0.25 \mathrm{U}$ of Hot Start Taq polymerase (Applied Biosystems) in a total volume of $20 \mu \mathrm{l}$. Cycling conditions for methylated and unmethylated strand of $\mathrm{miR}-34 \mathrm{~b} / \mathrm{c}$ were as follows: preheating at $95^{\circ} \mathrm{C}$ for $10 \mathrm{~min}$ followed by 40 cycles of denaturation at $95^{\circ} \mathrm{C}$ for $30 \mathrm{~s}$, annealing at $59^{\circ} \mathrm{C}$ for $30 \mathrm{~s}$ and extension at $72^{\circ} \mathrm{C}$ for $30 \mathrm{~s}$, and a final extension at $72^{\circ} \mathrm{C}$ for $7 \mathrm{~min}$. For unmethylated strand of miR-148a: preheating at $95^{\circ} \mathrm{C}$ for $10 \mathrm{~min}$ followed by 40

Table I Primers list for methylation-specific PCR for miR34b/c and miR-I48a, base pair and the annealing temperature ( $\left.T_{\mathrm{m}}\right)$ of PCR

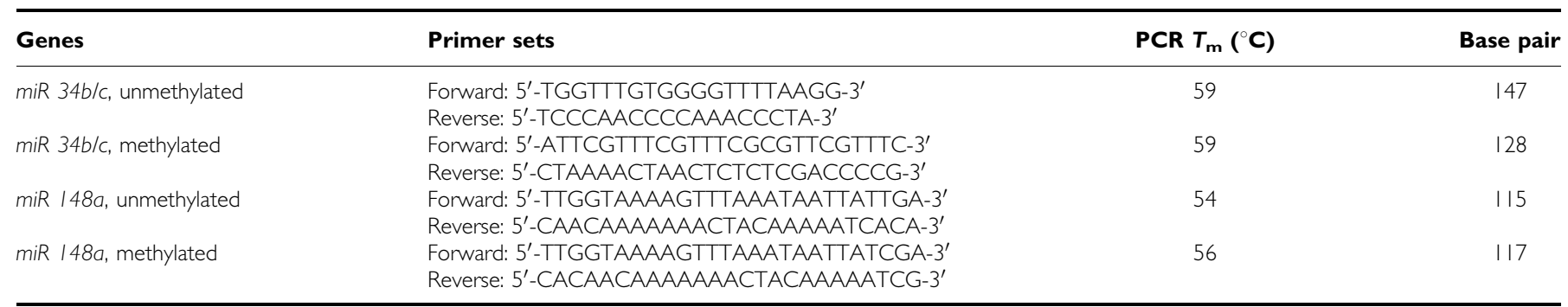


cycles of denaturation at $95^{\circ} \mathrm{C}$ for $30 \mathrm{~s}$, annealing at $54^{\circ} \mathrm{C}$ for $30 \mathrm{~s}$ and extension at $68^{\circ} \mathrm{C}$ for $30 \mathrm{~s}$, and a final extension at $68^{\circ} \mathrm{C}$ for $7 \mathrm{~min}$. For methylated strand of miR-148a: preheating at $95^{\circ} \mathrm{C}$ for $10 \mathrm{~min}$ followed by 40 cycles of denaturation at $95^{\circ} \mathrm{C}$ for $30 \mathrm{~s}$, annealing at $56^{\circ} \mathrm{C}$ for $30 \mathrm{~s}$ and extension at $72^{\circ} \mathrm{C}$ for $30 \mathrm{~s}$, and a final extension at $72^{\circ} \mathrm{C}$ for $7 \mathrm{~min}$. Qiagen's methylated and unmethylated control DNAs served as a reaction control for PCR.

\section{Preparation of faecal DNA}

Faecal DNA was obtained as previously described (Kalimutho et al, $2010 \mathrm{~b})$. Faecal DNA of average-risk individuals with no previous history of colon cancer or polyps $(n=39)$, CRC patients $(n=28)$ and polyps with HGD $(n=12)$, all provided written informed consent. DNA from each sample was then subjected to bisulfite conversion and then whole bisulfitome modification later for MSP. All assays were carried out in a blind manner by two different technicians.

\section{Whole bisulfitome amplification of bisulfite-converted faecal DNA}

Faecal DNA whole bisulfitome amplification was carried out using Whole Bisulfitome kit (Qiagen). This assay is based on REPLI-g technology to allow reproducible and representative amplification of bisulfite converted genomic (smaller DNA fragment size and changed nucleotide composition because of the bisulfite conversion), while maintaining the converted sequence representation. Briefly, bisulphited-converted DNA was added with REPLI-g Midi DNA Polymerase (Qiagen) and incubated at $28^{\circ} \mathrm{C}$ for $8 \mathrm{~h}$. Later the reaction mixtures were deactivated at $95^{\circ} \mathrm{C}$ for $5 \mathrm{~min}$ and the pre-amplified-converted DNA was subjected to $10 \times$ dilutions in $\mathrm{ddH}_{2} \mathrm{O}$ for MSP reaction.

\section{Statistical analysis}

Correlations between methylation status and clinicopathological features were assessed using v2 or Fisher's exact probability tests as appropriate. All $P$-values presented are two-sided. A $P$-value $<0.05$ was regarded as statistically significant. Survival curves were generated using Kaplan-Meier method. All statistical tests were performed using MedCalc (version 9.2.0.1, MedCalc, Mariakerke, Belgium) and SPSS (version 16.0, SPSS Inc, Somers, NY, USA) software package.

\section{RESULTS}

\section{MicroRNAs selection following AZA treatment}

To identify which miRNAs undergo specific epigenetic silencing at $5^{\prime}$ promoter flanking, we used a super-array RT - qPCR technique which can simultaneously detect miRNAs that have been silenced by epigenetic modification. This array consists of 46 miRNAs, which possessed a $\mathrm{CpG}$ island at the promoter region (identified by http://www.mirbase.org/ and http://www-bimas.cit.nih.gov/ molbio/proscan/ - predicted sequence regions which contain a significant number and type of transcriptional elements that are usually associated with Pol II promoter sequences) and with two endogenous control small RNAs (RNU19 and RNU6B) for data normalisation. We treated HCT116 and HT29 CRC cell lines with AZA and found elevated expression of 12 miRNAs (Table 2). Following this, we determined which miRNAs would have potential role in the tumour microenvironment. On the basis of the literature, we found that $\mathrm{miR}-34 \mathrm{~b} / \mathrm{c}$ was downregulated in most of cancers including colorectal and have tumour suppressor properties (He et al, 2005; Chang et al, 2007; Hermeking, 2010). In addition, miR-148a was correlated to the tumour metastasis which involved a panel of cancer models (Lujambio et al, 2008). Thus, based on these previous findings, we chose two miRNAs (miR-34b/c and miR-148a) for further evaluation using MSP in CRC fresh frozen and faecal specimens. We avoided selection of certain miRNAs from our list that were upregulated following AZA treatment for two reasons; (i) some miRNAs have been reported previously to be overexpressed in CRC vs matched tissues and (ii) we particularly looked for screening markers which would detect cancer more accurately than the available screening markers and with a high degree of sensitivity.

\section{Expression of miR-34b/c and miR-148a following AZA treatment}

Having determined that miR-34b/c and miR-148a were involved in cancer progression, we analysed these miRNAs to ensure that what we observed with super array technique was paralleled with single RT-qPCR analysis. To assess the effects of miR-34b/c and miR-148a promoter methylation, four CRC cell lines (HCT116, HT29, LoVo and HCT15) were further treated with AZA for 5 days. We found that all CRC cell lines responded concordantly to the AZA treatment as shown in Figures $1 \mathrm{~A}$ and B. For miR-34b/c, about a 6-fold change in expression level was observed followed by LoVo (3.3-fold), HT29 (3-fold) and HCT15 (2.5-fold; Figure 1A, upper panel). In contrast, in HT29 cells we found a strong increase in expression of miR-148a following AZA treatment (5-fold) followed by HCT15 (3-fold), LoVo (2.6-fold) and HCT116 cell lines (1.5-fold; Figure 1B, upper panel). These data suggested that the transcription of these miRNAs (miR-34b/c, miR-148a) were silenced by hypermethylation modification. The differences in expression levels of miRNAs following AZA treatment may also reflect the treatment efficiency. Next, we wanted to confirm whether the upregulated $\mathrm{miR}-34 \mathrm{~b} / \mathrm{c}$ and $\mathrm{miR}-148 \mathrm{a}$ expression

Table 2 miRNAs upregulation after the treatment with AZA

\begin{tabular}{|c|c|c|c|c|c|c|}
\hline & hsa-miR & HCTII 6 & HT29 & Expression in CRC & Functions & References \\
\hline l & $15 b$ & 1.43 & 2.29 & $\uparrow$ & Cell cycle & Xi et al (2006) \\
\hline 2 & 96 & 1.58 & 2.3 & $\uparrow$ & DNA repairs & Bandrés et al (2006); Sarver et al (2009) \\
\hline 3 & $99 a$ & 3.85 & 2.23 & $\uparrow$ & Cell inhibition & Chen et al (2008) \\
\hline 4 & $106 a$ & 1.23 & 2.15 & $\downarrow \uparrow$ & NA & Díaz et al (2008); Link et al (20l0) \\
\hline 5 & 129 & 2.6 & 2.56 & $\downarrow$ & Cell death & Bandres et al (2009); Huang et al (2009) \\
\hline 6 & $135 b$ & 1.75 & 2.02 & $\uparrow$ & DNA repairs & Wang et al (2010) \\
\hline 7 & 146 & 1.09 & 2.63 & $\downarrow \uparrow$ & Anti metastatic & Hurst et al (2009); Slattery et al (201 I) \\
\hline 8 & $148 \mathrm{a}$ & 1.05 & 3.96 & $\downarrow$ & Methylation & Lujambio et al (2008); Chen et al (2010) \\
\hline 9 & $181 \mathrm{c}$ & 3.62 & 1.94 & $\downarrow$ & Oncogenic suppresion & Hashimoto et al (2010) \\
\hline 10 & 219 & $\mid .31$ & 3.41 & $\uparrow$ & NA & Schetter et al (2008) \\
\hline | | & 338 & 1.85 & 2.47 & NA & NA & NA \\
\hline 12 & $34 \mathrm{~b} / \mathrm{c}$ & 2.8 & 3.1 & $\downarrow$ & Cell cycle and apoptosis & Toyota et al (2008) \\
\hline
\end{tabular}

Abbreviations: $A Z A=5$-aza-2'-deoxycytidine; $C R C=$ colorectal cancer; miRNAs = microRNAs; $N A=$ data not available. 
A
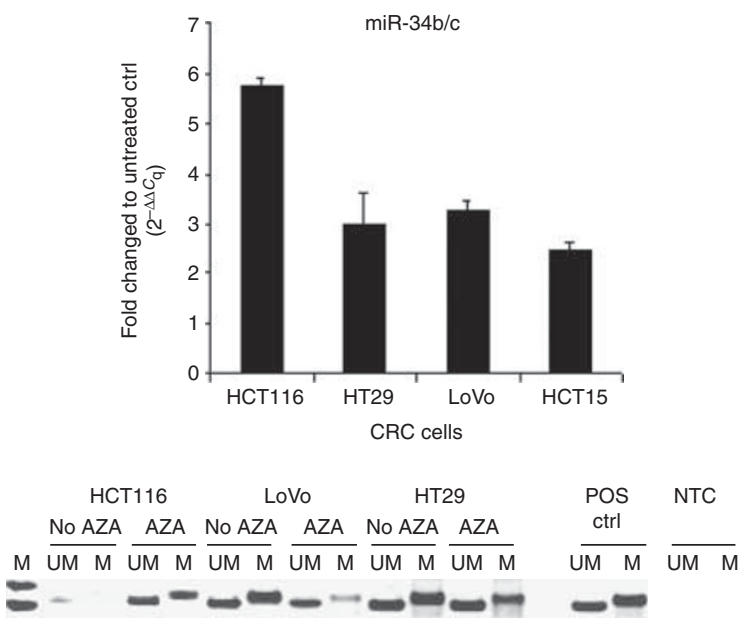

B

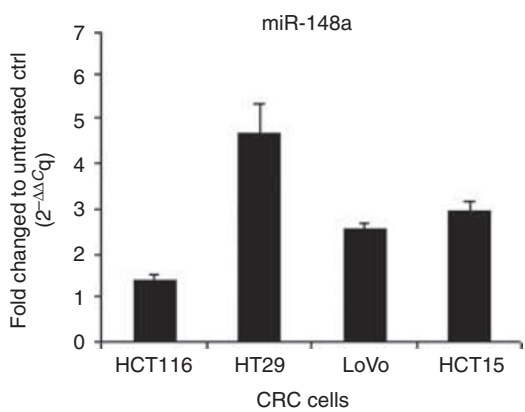

CRC cells

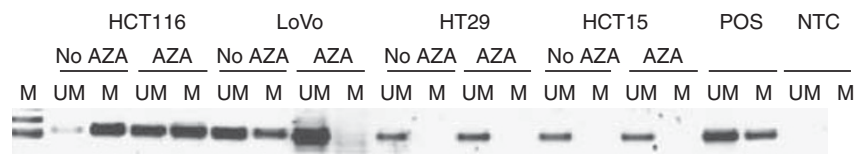

Figure I Methylation status of miR-34b/c and miR-I48a in a panel of CRC cell lines assessed by RT-qPCR and methylation-specific PCR (MSP). Fold change expression of miR-34b/c (A upper panel) and miR-I48a (B, upper panel) following $10 \mu \mathrm{M}$ demethylating agent 5-aza-2'-deoxycytidine over 5 days of incubation in HCTII6. HT29, LoVo and HCTI5 assessed by RT-qPCR and by means of a $2^{\wedge}-\Delta \Delta C_{\mathrm{q}}$ method. Corresponding methylation-specific PCR for miR-34b/c (A, lower panel) and miR-I48a (B, lower panel) showing the decrease in methylation pattern following $10 \mu \mathrm{M}$ demethylating agent 5-aza-2'-deoxycytidine. Lane UM and $M$ corresponded to unmethylated and methylated reaction respectively. Qiagen methylated and unmethlated control (ctrl) DNAs served as a reaction control for $\mathrm{PCR}$. NTC $=$ negative template control; $\mathrm{POS}=$ positive template control; $A Z A=5$-aza-2'-deoxycytidine.

observed by RT-qPCR was paralleled with MSP analysis. Restoration of $\mathrm{miR}-34 \mathrm{~b} / \mathrm{c}$ expression was more profound in LoVo and HT29 cells than HCT116 cells (Figure 1A, lower panel). In contrast, no methylation of miR-148a in HT29 and HCT15 cells was noticed, whereas more profound restoration of miR-148a expression was detected in LoVo than HCT116 cells as decreased in promoter methylation was detected by MSP (Figure 1B, lower panel).

\section{Analysis of promoter methylation of miR-34b/c in primary tumours and matched normal tissues using MSP}

First, we assessed the promoter methylation of miR-34b/c by MSP in 81 neoplastic colonic mucosa and 42 matched normal tissues (Table 3a, upper panel).

We found that $97.5 \%$ ( $n=79$ out of 81$)$ of neoplastic samples showed promoter methylation of miR-34b/c (Figures $2 \mathrm{~A}$ and $\mathrm{B}$ ). In
Table 3 Demographic of total patients analysed for both tumour and faecel samples

\begin{tabular}{lc}
\hline (A) Total of CRC tissue samples ( $n)$ & 122 \\
Median age both female and male (range) & $68.0(35-89)$ \\
CRC samples & \\
Male & 48 \\
Median age (range) & $69.5(42-84)$ \\
CRC samples & \\
Female & 33 \\
Median age (range) & $62(35-89)$ \\
Normal colon mucosa samples & 41 \\
Male & 28 \\
Median age (range) years & $68.5(52-84)$ \\
(B) Total of faecal samples ( $n$ ) & 79 \\
Median age both female and male (range) & $62(28-88)$ \\
Male & 32 \\
Median age (range) & $62(35-79)$ \\
CRC patients & 28 \\
Male & 13 \\
Median age (range) years & $66(49-79)$ \\
High-grade dysplasia & 12 \\
Male & 8 \\
Median age (range) years & $62(55-74)$ \\
CRClpolyp-free subjects & 39 \\
Male & 11 \\
Median age (range) years & $58(35-65)$ \\
\hline Abbrion &
\end{tabular}

Abbreviation: $\mathrm{CRC}=$ colorectal cancer

contrast, promoter methylation of miR-34b/c was only detected in $14.3 \%(n=6 / 42 ; P<0.001$; Figures $2 \mathrm{~A}$ and $\mathrm{B}$, Table 4$)$ of matched normal colonic tissues. No correlation were found for $\mathrm{miR}-34 \mathrm{~b} / \mathrm{c}$ methylation pattern with clinicopathological status except for one significant correlation for pTNM stage, $P=0.0110$ (Table 4). However, this result is conflicting as only two samples were not positive for stage II cancer.

\section{Promoter methylation of $\mathrm{miR}-34 \mathrm{~b} / \mathrm{c}$ detection in faeces of CRC patient}

Having confirmed that the expression of $\mathrm{miR}-34 \mathrm{~b} / \mathrm{c}$ is suppressed by methylation pattern in a large subset of CRC (97.5\%), we wanted to confirm whether the same methylated pattern could be detected in faecal specimens. We used previously extracted faecal DNA for MSP for miR-34b/c methylation detection (Table 3b, lower panel; Kalimutho et al, 2010b) and used REPLI-g technology to enhance the detection rate of low abundant methylated alles in faeces. This assay would pre-amplify the low abundant methylated copies, which is the main drawback in faecal-DNA methylation analysis. We found that $75 \%(n=21$ out of 28$)$ of CRC cases were positive for promoter methylation of miR-34b/c (Figure 2C, upper panel, Table 5). At the same time, we analysed colonoscopy faecal DNA from negative patients and found that only $13 \%(n=5$ out of 39) of cases had a positive methylation pattern for miR-34b/c. This result mirrored the data obtained for $\mathrm{miR}-34 \mathrm{~b} / \mathrm{c}$ in primary tissue samples (Table 4, Figure 2C, middle panel). Furthermore, we wanted to confirm whether the same methylated pattern could be observed in HGD. However, we found that only two cases were positive for miR-34b/c methylation, $n=12$ (Figure $2 \mathrm{C}$, lower panel, Table 5). 

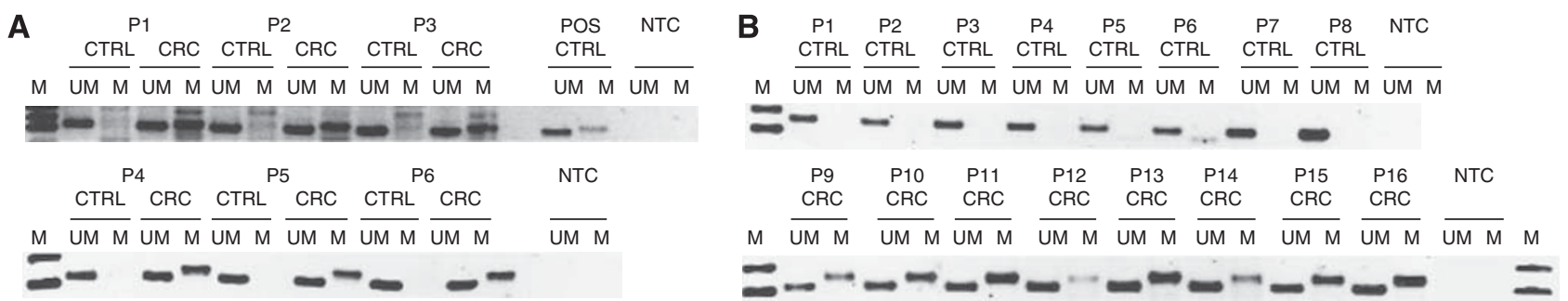

C

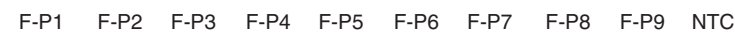

CRC CRC CRC CRC CRC CRC CRC CRC CRC

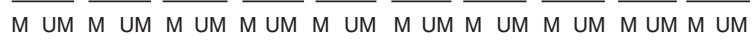

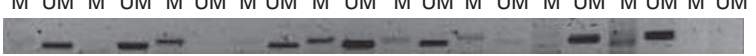

$\begin{array}{lllllllll}\text { F-P1 } & \text { F-P2 } & \text { F-P3 } & \text { F-P4 } & \text { F-P5 } & \text { F-P6 } & \text { F-P7 } & \text { F-P8 } & \text { NTC }\end{array}$

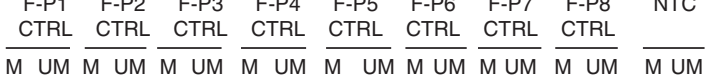

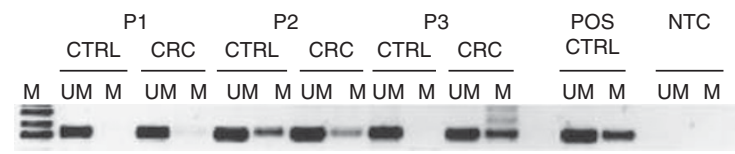

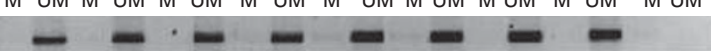

D

\begin{tabular}{lll} 
F-P9 & F-P10 & NTC \\
$\frac{\text { CTRL }}{M ~ U M}$ & $\frac{\text { CTRL }}{M ~ U M}$ & \\
\hline & &
\end{tabular}

Figure 2 Methylation-specific PCR (MSP) reactions for the miR-34b/c and miR-148a promoter region in tumour and faecal specimens derived from CRC and/or normal individual. (A and B) MSP analysis for miR-34b/c in matched CRC samples. (C) MSP analysis for miR-34b/c in faeces of CRC (upper panel), colonoscopy negative individuals (middle panel) and high-grade dysplasia (lower pane). (D) MSP analysis for miR-I48a in matched CRC tissues. Lane UM and $M$ corresponded to unmethylated and methylated reaction, respectively. Qiagen methylated and unmethylated control (CTRL) DNAs served as a reaction control for polymerase chain reaction. NTC $=$ negative template control; $\mathrm{POS}=$ positive template control; $\mathrm{P}=$ patients; $\mathrm{F}-\mathrm{PI}=$ samples derived from faeces of CRC and normal individuals.

\section{Promoter methylation of miR-148a and their correlation to clinicopathological features}

Next, we analysed the promoter methylation pattern of miR-148a on the same tumour samples analysed for miR-34b/c. We also wanted to correlate miR-148a methylation pattern with clinicopathological features. No significant correlation was found between miR-148a methylation status with clinicopathological features except for a trend (although not significant) with female gender $(P=0.08$; Table 4$)$, and with advanced age $(P=0.101)$. We found that stage III $(65 \%)$ and stage IV $(75 \%)$ disease were more prone to have methylated pattern for miR-148a but this was not significant. Moreover, pT4 tumours were fully methylated (100\%) compared with pT tumours in which only $65 \%$ were positive for methylation. Overall, $65 \%$ of CRC tumour tissues were positive for miR-148a methylation.

We also wanted to determine the prognostic value of miR-148a methylation status in this patient cohort. Surgical approach in patients with colon cancer consisted of standard hemicolectomy (via laparotomic or laparoscopic approach) with negative macroscopic resection margin and regional lymphadenectomy in all cases. The median number (range) of removed lymph nodes was 17 (3-56). In rectal cancer, laparotomic/laparoscopic low anterior resection or abdominoperineal resections with total mesorectal excision were performed; the median number of removed lymph nodes was 13 (range: 4-37). Overall survival was calculated according to the Kaplan-Meier method in 60 patients available for survival analysis, considering cancer related death as the end point. The median follow-up period was 46 months (range: 1-266 months). Comparison between survival curves was performed with the log-rank test. The 10-year survival rate of the entire series was $60 \%$ (Figure $3 \mathrm{~A}$ ). Survival was significantly related to the stage of the tumour, and depth of invasion was one of the most important prognostic factors (log-rank test: $P<0.05$; Figure 3B). Interestingly, we found a trend towards lower overall survival in the patients with methylated miR-148a alleles (10-year survival probability: 48\%) compared with patients with unmethylated miR-148a alleles (10-year survival probability: 65\%; Figure $3 \mathrm{C}$ ); however, the difference was not statistically significant (log-rank test: $P=0.561$ ) because of the small number of patients available for survival analysis.

\section{DISCUSSION}

Previous studies have shown that half of the miRNAs are located in or near CpG islands, which are transcriptionally regulated by DNA methylation process that varies between normal and tumour cells (Lujambio et al, 2007, 2008). For example, the methylation pattern of miR-124a is tumour specific, whereas miR-127 is methylated in both normal and tumour tissues (Saito et al, 2006; Lujambio et al, 2008), and let-7a-3 is methylated in normal tissues, whereas it shows a hypomethylation pattern in lung adenocarcinomas (Brueckener et al, 2007). However, the mechanism underlying the deregulation of miRNAs in cancer has not yet been fully elucidated.

With regard to this, we focused our study on the identification of miRNA with low expression in CRC and which may be involved in the development of CRC tumourigenesis. We evaluated expression levels of 46 miRNAs and found that 12 miRNAs were upregulated following AZA treatment. Of these, we decided to further investigate two miRNAs, $\mathrm{miR}-34 \mathrm{~b} / \mathrm{c}$ and $\mathrm{miR}-148 \mathrm{a}$, which also previously been reported (Lujambio et al, 2008; Toyota et al, 2008); however, the clinicopathological features have not been fully evaluated in colorectal tumours. Two other main reasons for selecting these miRNAs are: (i) first, to evaluate the methylation pattern of $\mathrm{miR}-34 \mathrm{~b} / \mathrm{c}$ in tumours tissues in order to extend the work of Toyata et al (2008) and to further evaluate it in faecal samples. This would allow us to develop faecal-DNA-based markers for CRC screening; (ii) second, miR-148a was correlated to metastasis properties, yet no clinical correlation with methylation pattern is available for CRC. We also reasoned that miRNAs may be 
Table 4 Association of miR-34b/c and miR-I48a methylation pattern with clinocopathological features in tumour tissue specimen

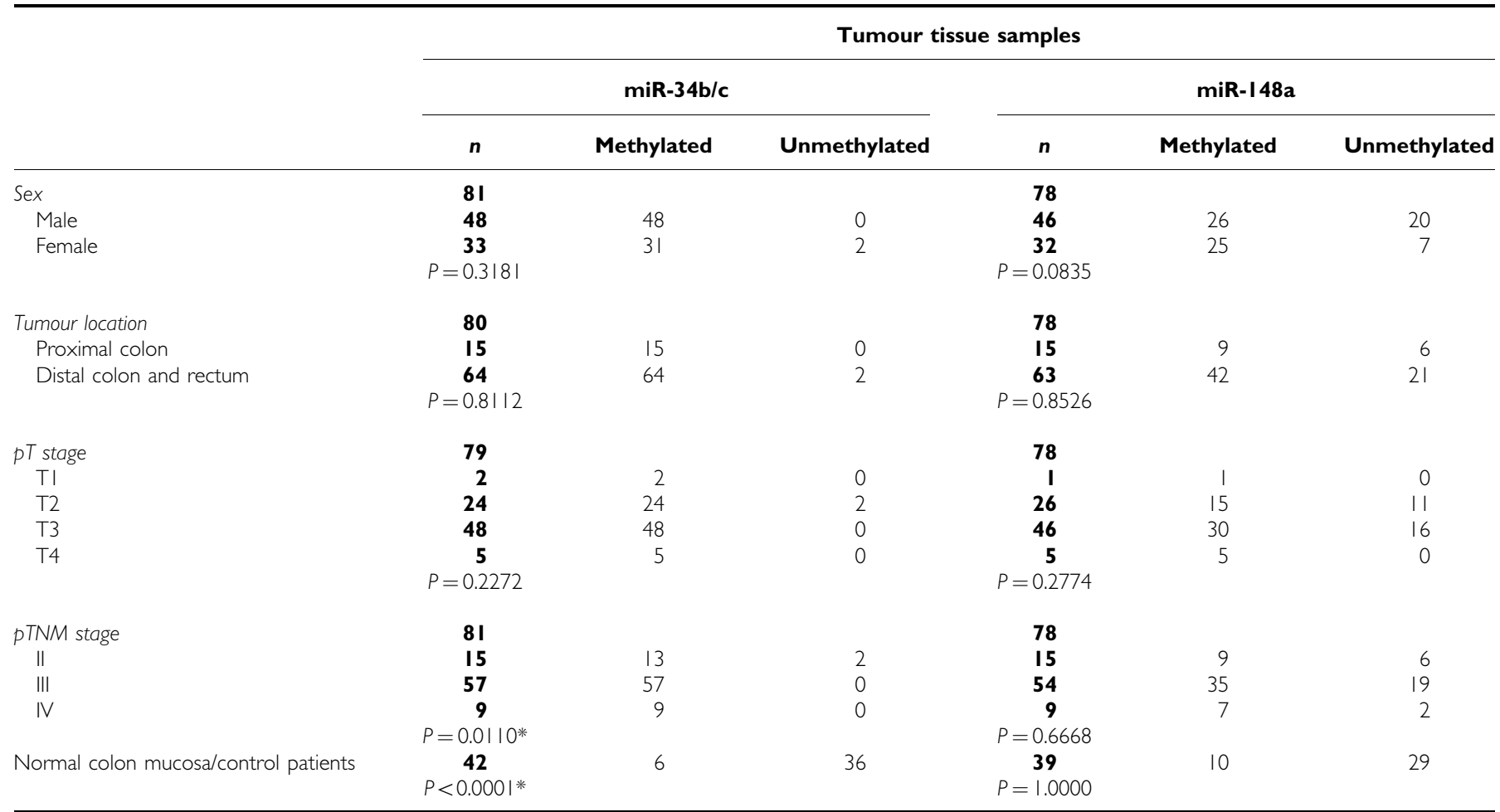

*P-value indicative significant data produced. The bold values indicate the total number of patients analyzed in this pilot study.

Table 5 Association of miR-34b/c methylation pattern with clinocopathological features in faecal specimen

\begin{tabular}{|c|c|c|c|c|}
\hline & \multicolumn{4}{|c|}{ Faecal samples } \\
\hline & \multirow[b]{2}{*}{$n=79$} & \multicolumn{2}{|c|}{ miR-34b-c } & \multirow[b]{2}{*}{$P$-values } \\
\hline & & Methylated & Unmethylated & \\
\hline Sex & 28 & & & \\
\hline Male & 13 & 10 & 3 & \\
\hline Female & 15 & 11 & 4 & $P=0.8268$ \\
\hline Tumour location & 28 & & & \\
\hline Proximal colon & 7 & 4 & 3 & \\
\hline $\begin{array}{l}\text { Distal colon and } \\
\text { rectum }\end{array}$ & 21 & 17 & 4 & $P=0.497$ \\
\hline pTNM stage & 28 & & & \\
\hline 0 & 5 & 3 & 2 & \\
\hline । & 2 & 2 & 0 & \\
\hline$\|$ & 6 & 3 & 3 & \\
\hline III & 3 & 2 & I & \\
\hline Unknown & 9 & 8 & 1 & \\
\hline Unclassified & 1 & I & 0 & \\
\hline a & 2 & 2 & 0 & $P=0.5055$ \\
\hline High-grade dysplasia & 12 & 2 & 10 & \\
\hline $\begin{array}{l}\text { Normal colon mucosa/ } \\
\text { control patients }\end{array}$ & 39 & 5 & 34 & $P<0.000$ I* \\
\hline
\end{tabular}

aHistology report not available, as the patients underwent chemoradiotheraphy or underwent surgery at a different location. ${ }^{*} P$-value indicative significant data produced.

a better class of tumour marker because of their broad regulatory functions and the ability to measure their expression levels with far better accuracy than is currently achievable for mRNA.
Thus, to further elucidate the role of these miRNAs, four CRC cell lines were treated with AZA, which allows us to demonstrate that reduced expression of both miRNAs is directly related to promoter methylation. The most striking evidence from our study is that the $\mathrm{CpG}$ island of the promoter region of $\mathrm{miR}-34 \mathrm{~b} / \mathrm{c}$ are hypermethylated in $97.5 \%$ CRC cases, and this methylation is, therefore believed to be tumour specific for CRC. The high percentage of methylation pattern in these CRC cases, and the contribution of miR-34 family on the p53 network, suggest that $\mathrm{miR}-34 \mathrm{~b} / \mathrm{c}$ may be involved in the response to colorectal tumourigenesis. As induction of cell cycle arrest, senescence and apoptosis are the mechanisms of oncosuppression by miR-34 family (Chang et al, 2007; Hermeking, 2010), permanent inactivation due to epigenetic silencing may result in a selective advantage for cancer cell proliferation. The first report by Toyata et al (2008) on methylation pattern revealed that $\mathrm{miR}-34 \mathrm{~b} / \mathrm{c}$ was aberrantly hypermethylated in primary CRC tumours. They showed that epigenetically silenced miR-34b/c could possibly be involved in the early process of tumourigenesis. Besides, Corney et al (2010) recently reported downregulation of $\mathrm{miR}-34 \mathrm{~b} / \mathrm{c}$ in ovarian cancer. They found that $\mathrm{miR}-34 \mathrm{~b} / \mathrm{c}$ is significantly reduced in stage IV compared with stage III tumours. Accordingly, their data support our observation in which methylation patterns are inversely correlated towards tumour stage in CRC. Furthermore, the results obtained by this study combined with our own observation, could correlate $\mathrm{miR}-34 \mathrm{~b} / \mathrm{c}$ hypermethylation status into the development of screening markers for CRC detection.

We further evaluated $\mathrm{miR}-34 \mathrm{~b} / \mathrm{c}$ methylation in faecal specimens. Alteration in the genome that would lead to the progression of cancer could be detected using faecal specimens from CRC patients. Faecal DNA analysis was shown to represent a novel noninvasive method for CRC detection (Dong et al, 2001; Kalimutho et al, 2010b). We found that almost 75\% of the CRC patients could be detected using faecal specimens. This is considered a good percentage to detect cancer using faeces as a screening marker, as 

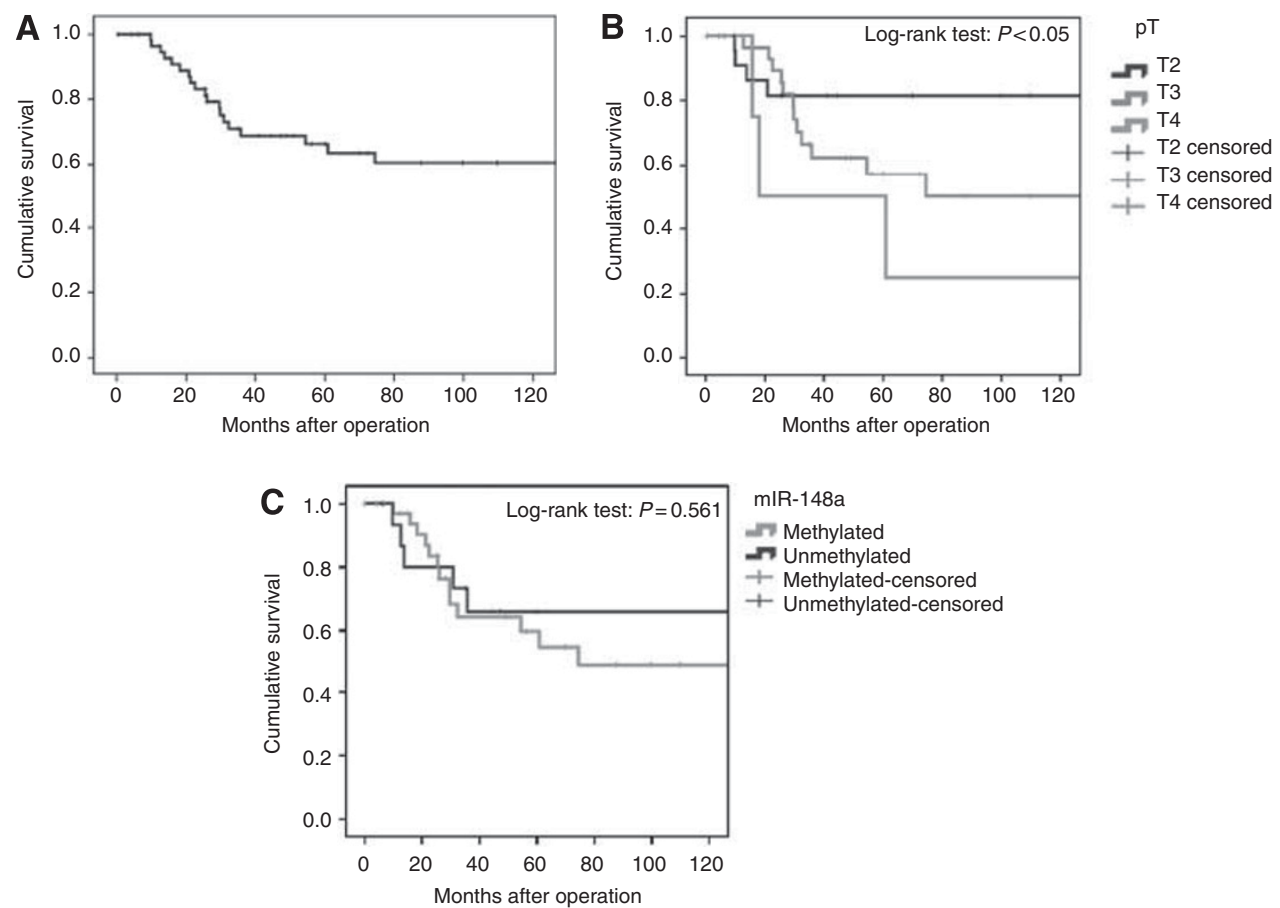

Figure 3 Box and Whisker plot and Kaplan-Meier disease-free survival analysis for CRC patients according to miR-I48a hypermethylation pattern. (A) The I0-year survival rate (60\%) of CRC patients was calculated using the Kaplan-Meier method. (B) Survival rate of CRC patients according to depth of invasion. The difference is statistically significant (log-rank test: $P<0.05)$. $(\mathbf{C})$ The prognostic value of miR-I48a methylation status was with a trend towards lower survival rate in patients with methylated alleles (10-year survival probability: 48\%) compared with unmethylated cases (I0-year survival probability: 65\%), log-rank test: $P=0.561$.

methylated faecal DNA is almost inflexible to detect in the complex microenvironment of faeces. Furthermore, our data are based on a small group of faecal analysis, thus a large randomised blind study should take place to evaluate the actual sensitivity of this marker for CRC screening. In addition, the low percentage of CRC detection in faeces compared with $98 \%$ in tumour samples maybe because of the nature of the technique used for MSP observation. Hence, more advanced techniques, such as pyrosequencing or even quantitative-MSP using a specific probe of minor groove binder, would enhance the detection rate of $\mathrm{miR}-34 \mathrm{~b} / \mathrm{c}$ in faeces. However, as the methylation pattern of miR-34b/c shows almost no trend on tumour stage and possesses a high level of promoter methylation state in CRC, both in tumour and feaces, this would facilitate the feasibility of assaying faecal $\mathrm{miR}-34 \mathrm{~b} / \mathrm{c}$ as an additional test in clinical settings.

Next, we wanted to see whether the hypermethylation of miR-148a could correlate into clinicopathological features of CRC. The miR-148a expression is shown to be downregulated in human breast cancer and undifferentiated in gastric cancer (Lehmann et al, 2008; Katada et al, 2009). DNA methylationassociated silencing of miR-148 expression is identified in human cancer cell lines established from lymph node metastasis of colon, melanoma, and head and neck cancer, suggesting its role in the development of metastasis (Lujambio et al, 2008). Duursma et al (2008) have shown that overexpression of miR-148a leads to a reduction in the expression of de novo DNA-methyl-transferase-3b (DNMT3b) enzyme. The suppression of miR-148a, in contrast, induces increased expression of DNMT3b. The evidence shows that alteration of DNMT3b expression clearly contributes to CRC tumourigenesis. Lin et al (2006) as well Jin et al (2009) showed that the increased expression patterns of DNMT3b protein in $\mathrm{Apc}^{\mathrm{Min} /+}$ increases colorectal carcinogenesis because of the hypermethylation of tumour suppressors genes. Also, Ahmed et al (2008) showed that reducing expression of DNMT3b in PC3 tumour cells induces the loss of methylation at the promoters of several tumour suppressor genes such as APC, RB1 and RER- $\beta$. Therefore, methylation at the promoter of miR-148a leads to increased expression of DNMT3b, which in turn inactivates its tumour suppressor function in most of the cancers. The correlation of our data with miR-148a promoter methylation pattern, together with Lujambio et al (2008), allows us to link the epigenetically silenced miR-148a with the progression to advanced tumour stage. For example, $65 \%(n=30$ out of 46$)$ of patients with stage T3, $100 \%(n=5)$ stage T4 and $78 \%(n=7$ out of 9$)$ with stage N2 of CRC, have a condition of promoter methylation of miR-148a. Very recently, Chen et al (2010) reported the downregulation of miR-148a and miR-152 in gastric and CRC by expression analysis in which they found a strong correlation between these two miRNAs. In support of our data, they also reported that no statistical correlation was found with clinicopathological features including sex, age, tumour location, histological grade, $\mathrm{pN}$ stage or lymphatic vessel invasion in gastrointestinal cancers. Despite this, we observed that the positive cases of promoter methylation of miR-148a have a lower survival rate than the negative cases (48 vs $65 \%$ at 10 years). In addition, the number of cases in our patient cohort is too small to investigate a potential impact of treatment stratified according to miR-148a methylation status, and this may represent a clinical limitation of this study. Further prospective studies may be designed in order to assess the potential clinical utility of multimodality treatments in tumours with more aggressive biology, identified by miR-148a expression.

In conclusion, as many CRC patients present with advanced disease, early detection leads to reduced mortality. Therefore, developing a miR-34b/c methylation assay as a diagnostic tool for early detection of CRC would have substantial clinical benefits. On the other hand, follow-up for the disease progression with targeted molecular markers such as miR-148a would enable classification of the prognosis of the disease as well as being a tool for therapy monitoring in patients having had CRC. Moreover, the reduced expression of $\mathrm{miR}-34 \mathrm{~b} / \mathrm{c}$ and $\mathrm{miR}-148 \mathrm{a}$ because of the epigenetic 
silencing could be considered as an important target of antineoplastic therapy development.

\section{ACKNOWLEDGEMENTS}

This work was supported by grants from the University Hospital Tor Vergata, University of Rome. MK was supported by the predoctoral scholarship for foreign student under the International
Italian Government University scholarship scheme. We thank to Dr Sandra Van Schaeybroeck, Queen's University, Belfast for the critical reading of the manuscript.

\section{Conflict of interest}

The authors declare no conflict of interest.

\section{REFERENCES}

Ahmed Y, Sohail AQ, Romena Q, Abbas F (2008) Down-regulation of DNMT3b in PC3 cells effects locus-specific DNA methylation, and represses cellular growth and migration. Cancer Cell Int 8: 13

Bandres E, Agirre X, Bitarte N, Ramirez N, Zarate R, Roman-Gomez J, Prosper F, Garcia-Foncillas J (2009) Epigenetic regulation of microRNA expression in colorectal cancer. Int J Cancer 125: 2737-2743

Bandrés E, Cubedo E, Agirre X, Malumbres R, Zárate R, Ramirez N, Abajo A, Navarro A, Moreno I, Monzó M, García-Foncillas J (2006) Identification by real-time PCR of 13 mature microRNAs differentially expressed in colorectal cancer and non-tumoral tissues. Mol Cancer 19: 29

Barbarotto E, Schmittgen TD, Calin GA (2008) MicroRNAs andcancer: profile, profile, profile. Int J Cancer 122: $969-977$

Bartel DP (2004) MicroRNAs: genomics, biogenesis, mechanism, and function. Cell 116: $281-297$

Brueckener B, Stresemann C, Kuner R, Mund C, Musch T, Meister M, Sültmann H, Lyko F (2007) The human let-7a-3 locus contains an epigenetically regulated microRNA gene with oncogenic function. Cancer Res 67: 1419-1423

Calin GA, Dumitru CD, Shimizu M, Bichi R, Zupo S, Noch E, Aldler H, Rattan S, Keating M, Rai K, Rassenti L, Kipps T, Negrini M, Bullrich F, Croce CM (2002) Frequent deletions anddown-regulation of micro-RNA genes miR15 and miR16 at13q14 in chronic lymphocytic leukemia. Proc Natl Acad Sci USA 99: 15524-15529

Calin GA, Sevignani C, Dan Dumitru C, Hyslop T, Noch E, Yendamuri S, Shimizu M, Rattan S, Bullrich F, Negrini M, Croce CM (2004) Human microRNA genes are frequently located at fragile sites and genomic regions involved in cancers. Proc Natl Acad Sci USA 101: 2999-3004

Chang TC, Wentzel EA, Kent OA, Ramachandran K, Mullendore M, Lee KH, Feldmann G, Yamakuchi M, Ferlito M, Lowenstein CJ, Arking DE, Beer MA, Maitra A, Mendell JT (2007) Transactivationof miR-34a by p53 broadly influences gene expression and promotes apoptosis. Mol Cell 26: $745-752$

Chen X, Ba Y, Ma L, Cai X, Yin Y, Wang K, Guo J, Zhang Y, Chen J, Guo X, Li Q, Li X, Wang W, Zhang Y, Wang J, Jiang X, Xiang Y, Xu C, Zheng P, Zhang J, Li R, Zhang H, Shang X, Gong T, Ning G, Wang J, Zen K, Zhang J, Zhang CY (2008) Characterization of microRNAs in serum: a novel class of biomarkers for diagnosis of cancer and other diseases. Cell Res 18: $997-1006$

Chen Y, Song Y, Wang Z, Yue Z, Xu H, Xing C, Liu Z (2010) Altered expression of MiR-148a and MiR-152 in gastrointestinal cancers and its clinical significance. J Gastrointest Surg 14(7): $1170-1179$

Corney DC, Hwang CI, Matoso A, Vogt M, Flesken-Nikitin A, Godwin AK, Kamat AA, Sood AK, Ellenson LH, Hermeking H, Nikitin AY (2010) Frequent downregulation of miR-34 family in human ovarian cancers. Clin Cancer Res 6(4): 1119-1128

Díaz R, Silva J, García JM, Lorenzo Y, García V, Peña C, Rodríguez R, Muñoz C, García F, Bonilla F, Domínguez G (2008) Deregulated expression of miR-106a predicts survival in human colon cancer patients. Genes Chromosomes Cancer 47: 794-802

Dong SM, Traverso G, Johnson C, Geng L, Favis R, Boynton K, Hibi K, Goodman SN, D'Allessio M, Paty P, Hamilton SR, Sidransky D, Barany F, Levin B, Shuber A, Kinzler KW, Vogelstein B, Jen J (2001) Detecting colorectal cancer in stool with the use of multiple genetic targets. $J$ Nat Can Ins 93(11): 858-865

Duursma AM, Kedde M, Schrier M, le Sage C, Agami R (2008) miR-148 targets human DNMT3b protein coding region. RNA 14(5): $872-877$

Felicetti F, Errico MC, Bottero L, Segnalini P, Stoppacciaro A, Biffoni M, Felli N, Mattia G, Petrini M, Colombo MP, Peschle C, Carè A (2008) The promyelocyticleukemia zinc finger-microRNA-221/-222 pathwaycontrols melanoma progression through multiple oncogenicmechanisms. Cancer Res 68: $2745-2754$
Grady WM, Parkin RK, Mitchell PS, Lee JH, Kim YH, Tsuchiya KD, Washington MK, Paraskeva C, Willson JK, Kaz AM, Kroh EM, Allen A, Fritz BR, Markowitz SD, Tewari M (2008) Epigeneticsilencing of the intronic microRNA hsa-miR-342 and its hostgene EVL in colorectal cancer. Oncogene 27: $3880-3888$

Gramantieri L, Ferracin M, Fornari F, Veronese A, Sabbioni S, Liu CG, Calin GA, Giovannini C, Ferrazzi E, Grazi GL, Croce CM, Bolondi L, Negrini M (2007) Cyclin G1 is atarget of miR-122a, a microRNA frequently down-regulated inhuman hepatocellular carcinoma. Cancer Res 67: 6092-6099

Hashimoto Y, Akiyama Y, Otsubo T, Shimada S, Yuasa Y (2010) Involvement of epigenetically silenced microRNA-181c in gastric carcinogenesis. Carcinogenesis 31: $777-784$

He L, Thomson JM, Hemann MT, Hernando-Monge E, Mu D, Goodson S, Powers S, Cordon-Cardo C, Lowe SW, Hannon GJ, Hammond SM (2005) A microRNA polycistron as a potential human oncogene. Nature 435: $828-833$

Hermeking H (2010) The miR-34 family in cancer and apoptosis. Cell Death Differ 17: 193 - 199

Huang ZM, Yang J, Shen XY, Zhang XY, Meng FS, Xu JT, Zhang BF, Gao HJ (2009) MicroRNA expression profile in non-cancerous colonic tissue associated with lymph node metastasis of colon cancer. J Dig Dis 10: 188-194

Hurst DR, Edmonds MD, Welch DR (2009) Metastamir: the field of metastasis-regulatory microRNA is spreading. Cancer Res 69: 7495-7498

Hurteau GJ, Carlson JA, Spivack SD, Brock GJ (2007) Overexpressionof the microRNA hsa-miR-200c leads to reducedexpression of transcription factor 8 and increased expression of E-cadherin. Cancer Res 67: $7972-7976$

Jin B, Yao B, Li JL, Fields CR, Delmas AL, Liu C, Robertson KD (2009) DNMT1 and DNMT3B moldulate distinct polycomb-mediated histone modifications in colon cancer. Cancer Res 69(18): 7412-7421

Johnson SM, Grosshans H, Shingara J, Byrom M, Jarvis R, Cheng A, Labourier E, Reinert KL, Brown D, Slack FJ (2005) RAS is regulatedby the let-7 microRNA family. Cell 120: 635-647

Kalimutho M, Del Vecchio Blanco G, Gravina P, Cretella M, Mannucci L, Mannisi E, Formosa A, Pallone F, Federici G, Bernardini S (2010b) Quantitative denaturing high performance liquid chromatography (dHPLC) detection of APC long DNA and mutations in faeces from colorectal cancer patients. Clin Chem Lab Med 48(9): 1303-1311

Kalimutho M, Minutolo A, Grelli S, Formosa A, Sancesario G, Valentini A, Federici G, Bernardini S (2010a) Satraplatin (JM-216) mediates $\mathrm{G}_{2} / \mathrm{M}$ cell cycle arrest and potentiates apoptosis via multiple death pathways in colorectal cancer cells thus overcoming platinum chemoresistance. Cancer Chemother Pharmacol; First published online on 24 August 2010, doi:10.1007/s00280-010-1428-4

Katada T, Ishiguro H, Kuwabara Y, Kimura M, Mitui A, Mori Y, Ogawa R, Harata K, Fujii Y (2009) microRNA expression profile in undifferentiated gastric cancer. Int J Oncol 34: $537-542$

Krek A, Grun D, Poy MN, Wolf R, Rosenberg L, Epstein EJ, MacMenamin P, da Piedade I, Gunsalus KC, Stoffel M, Rajewsky N (2005) Combinatorial microRNA target predictions. Nat Genet 37: 495-500

Lee EJ, Gusev Y, Jiang J, Nuovo GJ, Lerner MR, Frankel WL, Morgan DL, Postier RG, Brackett DJ, Schmittgen TD (2007) Expression profiling identifies microRNA signature in pancreatic cancer. Int J Cancer 120: 1046 - 1054

Lee RC, Feinbaum RL, Ambros V (1993) The C. elegans heterochronic gene lin-4 encodes small RNAs with antisense complementarity to lin-14. Cell 75: $843-854$

Lehmann U, Hasemeier B, Christgen M, Muller M, Romermann D, Langer F, Kreipe H (2008) Epigenetic inactivation of microRNA gene hsa-mir-91 in human breast cancer. J Pathol 214: $17-24$ 
Lin H, Yamada Y, Nguyen S, Linhart H, Jackson-Grusby L, Meissner A Meletis K, Lo G, Jaenisch R (2006) Suppression of intestinal neoplasia by deletion of Dnmt3b. Mol Cell Biol 26(8): 2976-2983

Link A, Balaguer F, Shen Y, Nagasaka T, Lozano JJ, Boland CR, Goel A (2010) Fecal microRNAs as novel biomarkers for colon cancer screening. Cancer Epidemiol Biomarkers Prev 19: 1766 - 1774

Lujambio A, Calin GA, Villanueva A, Ropero S, Sánchez-Céspedes $M$, Blanco D, Montuenga LM, Rossi S, Nicoloso MS, Faller WJ, Gallagher WM, Eccles SA, Croce CM, Esteller M (2008) A microRNA DNA methylation signature for human cancer metastasis. Proc Natl Acad Sci USA 105: $13556-13561$

Lujambio A, Ropero S, Ballestar E, Fraga MF, Cerrato C, Setién F, Casado S, Suarez-Gauthier A, Sanchez-Cespedes M, Git A, Spiteri I, Das PP, Caldas C, Miska E, Esteller M (2007) Genetic unmasking of an epigenetically silenced microRNA in human cancer cells. Cancer Res 67: 1424-1429

Masters JRW, Twentyman P, Arlett C, Daley R, Davis J, Doyle A, Dyer S, Freshney I, Galpine A, Harrison M, Hurst H, Kelland L, Stacey G, Stratford I, Ward TH (2000) UKCCCR guidelines for the use of cell lines in cancer research. Br J of Cancer 82(9): $1495-1509$

Michael MZ, O’ Connor SM, van Holst Pellekaan NG, Young GP, James RJ (2003) Reduced accumulation of specific microRNAs in colorectal neoplasia. Mol Cancer Res 1(12): $882-891$

Mitomo S, Maesawa C, Ogasawara S, Iwaya T, Shibazaki M, Yashima-Abo A, Kotani K, Oikawa H, Sakurai E, Izutsu N, Kato K, Komatsu H, Ikeda K, Wakabayashi G, Masuda T (2008) Downregulationof miR-138 is associated with overexpression of humantelomerase reverse transcriptase protein in human anaplasticthyroid carcinoma cell lines. Cancer Sci 99: $280-286$

Saito Y, Liang G, Egger G, Friedman JM, Chuang JC, Coetzee GA, Jones PA (2006) Specific activation of microRNA-127 with down-regulation of the proto-oncogene BCL6 by chromatin-modifying drugs in human cancer cells. Cancer cell 9: $435-443$

Sarver AL, French AJ, Borralho PM, Thayanithy V, Oberg AL, Silverstein KA, Morlan BW, Riska SM, Boardman LA, Cunningham JM,
Subramanian S, Wang L, Smyrk TC, Rodrigues CM, Thibodeau SN, Steer CJ (2009) Human colon cancer profiles show differential microRNA expression depending on mismatch repair status and are characteristic of undifferentiated proliferative states. BMC Cancer 18: 401

Sassen S, Miska EA, Caldas C (2008) MicroRNA-implications for cancer. Virchows Arch 452: 1 - 10

Schetter AJ, Leung SY, Sohn JJ, Zanetti KA, Bowman ED, Yanaihara N, Yuen ST, Chan TL, Kwong DL, Au GK, Liu CG, Calin GA, Croce CM, Harris CC (2008) MicroRNA expression profiles associated with prognosis and therapeutic outcome in colon adenocarcinoma. JAMA 299: $425-436$

Shi XB, Xue L, Yang J, Ma AH, Zhao J, Xu M, Tepper CG, Evans CP, Kung HJ, deVere White RW (2007) An androgen-regulatedmiRNA suppresses Bak1 expression and induces androgen independent growth of prostate cancer cells. Proc Natl Acad Sci USA 104: $19983-19988$

Slattery ML, Wolff E, Hoffman MD, Pellatt DF, Milash B, Wolff RK (2011) MicroRNAs and colon and rectal cancer: differential expression by tumor location and subtype. Genes Chromosomes Cancer 50: $196-206$

Toyota M, Suzuki H, Sasaki Y, Maruyama R, Imai K, Shinomura Y, Tokino T (2008) Epigenetic silencingof microRNA-34b/c and B-cell translocation gene 4 is associatedwith $\mathrm{CpG}$ island methylation in colorectal cancer. Cancer Res 68: $4123-4132$

Wang YX, Zhang XY, Zhang BF, Yang CQ, Chen XM, Gao HJ (2010) Initial study of microRNA expression profiles of colonic cancer without lymph node metastasis. J Dig Dis 11: 50-54

Wienholds E, Kloosterman WP, Miska E, Alvarez-Saavedra E, Berezikov E, de Bruijn E, Horvitz RH, Kauppinen S, Plasterk RH (2005) MicroRNA expression in zebrafish embryonic development. Science 309: $310-311$

Xi Y, Formentini A, Chien M, Weir DB, Russo JJ, Ju J, Kornmann M, Ju J (2006) Prognostic values of microRNAs in colorectal cancer. Biomark Insights 2: 113-121 